\title{
CIRCULAR ECONOMY AS AN IMPORTANT SUBJECT OF ENVIRONMENTAL EDUCATION IN THE ERA OF ENERGY DEMAND
}

\author{
ANDRZEJ KLUCZKOWSKI, MICHAE WYROSTKIEWICZ
}

\begin{abstract}
Civilization development has led to many facilities in human life and business, but has also introduced major changes and created a new order that over time has come to be in opposition to nature. The opportunity to reconcile ecological, economic and social reasons is to be found in the idea of sustainable development. The prerequisite for achieving sustainable development is education, which is one of the fundamental human rights that enables integral development. The purpose of the study was to verify the role and importance of education in the emergence and implementation of a circular economy idea. As it turned out, research has shown that sustainable development is largely dependent on the implementation of the circular economy, in which, the education is a fundamental and necessary tool.
\end{abstract}

Keywords: ecology, sustainable development, education, circular economy, ecological competences.

\section{INTRODUCTION}

Civilizational progress, which has been quite intensive since the end of the 18th century, is undoubtedly good for man. It is not difficult to see that it makes life more comfortable, i.e. the difficulties with health, experience and the realization of various everyday tasks are reduced. Even more important is that it enables the updating of rationality, which is one of the basic needs of manperson. It will not be an exaggeration to say that thanks to the progress of civilization man becomes more and more human; He realizes himself as a rational and at the same time free person. Obviously, progress alone is not enough for the human person to reach the peak/ultimate of his integral development, but there is no doubt that development is an essential part of this development [1].

The above-mentioned point of view is only part of the truth. Stopping at these theses would mean reductive approach. A broad view of the current situation of man and of the whole world leads us to conclusion that the technical progress, which always implies interference in nature, and depends on the energy derived from the processing of the elements of nature alongside the unquestionable achievements and the mentioned positive factors, causes also exhaustion of natural resources, and consequent biosphere depletion and biodiversity loss what results in ecological imbalances in the world. Today's model of social and economic progress is based on a continuous increase of the 
consumption of goods and services, fuels including fossil fuels, energy sources, automotive development, disposable products production and waste accumulation. This inevitably leads to destruction of ecosystems, from which man is dependent in his biological existence, and thus also in his integral development. There is a paradox here: man on the one hand makes a lot of effort to raise his level of existence and make it easier, and on the other hand, to do so, to obtain the energy necessary for his work, degrades the nature of which he is a part and on which he is dependent [2].

A deliberate attempt to avoid self-destruction, while pursuing high-quality civilization progress, is the idea of the sustainable development [3]. Sustainability is one of the greatest challenges facing the $21^{\text {st }}$ century society and industry, and only the radical metamorphosis of existing systems can provide the opportunity for future generations [4]. The realization of the assumptions of sustainable development, i.e. the concern for the state of the environment, is not possible without the dissemination and implementation of the circular economy (CE). Even more: $\mathrm{CE}$ appears as a necessary condition for modern sustainable development.

Considering what has been signaled out above, it cannot be doubted that CE should be one of the fundamental issues of contemporary education. Understanding it and integrating into life, as has already been pointed out, is an essential factor in the integral development of an integral human being, which in turn is one of the fundamental goals of broadly understood education [5].

This text is not a simple description of CE. Showing the importance of this concept for human life and the existence of the Earth is an attempt to make this educational content. The importance and role of education for $\mathrm{CE}$ is a fundamental research problem. The paper presents the subject, aims and principles of education for the $\mathrm{CE}$ in the context of education for sustainable development, which was demonstrated without the CE and CE education would not be feasible.

\section{ANALYSIS AND DisCUSSION}

\subsection{Sustainability Concept - Definition, Genesis And PuRPose}

Sustainable development is a term still gaining in popularity, used for years in scientific literature, legal acts or strategic documents, such as the decrees and directives of the European Parliament. Although the essence of this concept seems quite understandable, the definition and precise interpretation of what sustainable development means, raises heated discussions [6]. Applied in specialist literature as English technical expression sustainable development was originally translated literally as self-sustaining development. In Polish literature, it is used under different concepts: sustainable development, permanent development, or as eco-development [7]. All these terms as a common goal assume the development of such mechanisms and ways of working so that further civilization development can be achieved while preserving the laws of nature.

The concept of sustainable development was adopted after the $1980^{\mathrm{s}}$ and shaped the work of the UN international body in the context of the UN Human Nature Conference in 1972, the work of the UN Environment and Development Committee and the Rio Earth Summit in Rio de Janeiro in 1992. The last of these was the Earth Charter (the Rio Declaration) - a general "philosophy" of sustainable development, and Agenda 21 - a document describing the ways, principles, and mechanisms for implementing this concept.

The classic definition of sustainable development is given by the UNCED - sustainable development is the one that faces the present without compromising the ability of future generations to meet their needs [8]. In a similar way, I define the sustainable development of UNESCO by emphasizing that the creation of a fully sustainable life model, and thus the improvement of the quality of life for people all over the world, must take place without the robbery of the earth's natural resources [9]. The Law on Environmental Protection of 27 April 2001 defines the concept of sustainable development as: "such a socio-economic development, in which the process of integrating political, economic and social activities takes place, preserving the natural balance and the sustainability of basic 
natural processes to meet the basic needs of individual communities or citizens of both the present and future generations" [10].

Sustainable development is the pursuit of reconciliation of environmental (economic deterioration), economic (satisfying basic needs) and social needs (securing minimum social benefits, health protection, development of the human spirit - culture, security and education) [7]. The ecological aspect means the establishment of the boundaries of the natural system for human activities and not exceeding them. The economic aspect is not only to meet today's needs, but to secure the resources needed for future generations. On the other hand, the social aspect is identified with education and ability to solve major social problems.

The concept of sustainable development offers a qualitatively new form of conscious, responsible life both individual and social on the basis of development together with the broadly understood environment and not only confined to the natural environment. In this sense, it appears as an educational concept - that is, the one that can change human thinking.

\subsection{IDEA AND PURPOSE OF A CiRCULAR ECONOMY}

As has already been shown, the idea of "sustainable development is to preserve the environment (raw materials) for the sake of the existence and development of future generations. The Rio Declaration on Environment and Development states that people at the center of sustainable development have a right to a healthy and creative life in harmony with nature (Principle 1), and environmental protection must be an integral part of other development processes and cannot be separated from it (Principle 4)" [11]. The CE concept is the longest preservation of added value of products (their usability) and the elimination of waste. The end of product's life cycle, in a linear model means the following sequence: production - use - waste disposal. By closing the product life cycle we get the sequence: production - utilization - waste utilization in the next production cycle. The essence of this approach is to use waste generated in the product life cycle and thus reduce the consumption of raw materials (the energy needed to extract them), reduce the amount of waste deposited and increase the waste stream used for recovery and recycling. Throughout the product lifecycle, from product design, production, consumption, to waste management, a comprehensive approach to products and services can provide raw material efficiency, both in the context of energy and material resources needed for production and significantly influence further economic development. Waste - If produced - should be treated as secondary raw materials. CE is responding to the challenges of limited access to natural resources and their excessive, often abusive exploitation.

In conclusion, it must be noted that the idea of CE enables further development of the man to whom he is called, while preserving the environment, resources and energy sources for subsequent generations. In times of depletion of commodities, rising prices, only a circular economy can provide sustainable sustainability. As you can see, the CE is fully in line with the basic assumptions of education, which is supposed to lead to the development of an integral human person. In today's world, which has been mentioned many times - nature is heavily exploited and CE appears as a necessary element of education conducted at every level.

\subsection{EdUCATION - THE NEED FOR ECOlOGiCAl AWARENESS}

The prerequisite for achieving sustainable development and an important tool for good governance is education, which is one of the fundamental human rights that enables it to develop integral. Openness to knowledge is an opening to development, one cannot fail to perceive the place and role of education in the development of the person. The process of education cannot be confined to the intellectual sphere. True education must be based on a multi-faceted vision of the person [1]. Therefore, education for the $\mathrm{CE}$ can help to make our vision of the future a reality. 


\subsubsection{EDUCATION FOR SUSTAINABLE DeVElOPMENT}

Education for sustainable development, which CE is an important element, shapes and strengthens the ability to assess the reality and people, social groups, organizations and states. It influences the way people think and allows people to create a safer, healthier and more prosperous world, thereby improving the quality of life [12]. The core of this education, as mentioned in the European Strategy for Education for Sustainable Development, is striving for a balance between social and economic wellbeing, tradition and nature; understanding and sense of human dignity, respect for diversity and protection of the environment and resources; awareness of the values of solidarity, equality and solidarity, social harmony and mutual respect; providing each unit with education opportunities that match its capabilities. Such education is a prerequisite for the introduction of the concept of sustainable development [13].

In practice, education for sustainable development means far more than just environmental education, although the latter is an important component of a person's education. According to UNESCO, education for sustainable development means education that:

- enables the learner to acquire the skills, knowledge and characteristics that ensure his/her sustainable development;

- is focused on criticism and problem solving, that is, the ability to cope with dilemmas and challenges of sustainable development;

- is equally accessible at all levels and in all social contexts (family, school, workplace, local community);

- builds civic responsibility and promotes democracy by making the individual aware of his or her rights and obligations;

- is based on the principle of lifelong learning;

- uses a variety of educational methods, seeking creative ways to express new ideas;

- local concerns, not just global issues [9].

The subject of education for sustainable development takes into account three areas: economic, social and ecological. Restoration of this triadic balance and stability, preserving the principle of interconnection, consisting in connecting all civilizational activities and their products and nature as their medium. Only this approach can guarantee and secure the future of modern society [14]. In addition to acquiring knowledge, it results in the person being educated in the harmonious development of her innate predispositions, acquiring the principles of self-knowledge and of the whole reality [1]. It is the acquisition of competences that an individual should possess, which will enable him to move freely and adapt to the changing processes [15].

\subsubsection{Circular Economy ANd Ecological Competences}

Education is the process of transferring knowledge, shaping specific traits and skills [16]. Informal education is a lifelong process that shapes values, attitudes, skills and knowledge. As previously pointed out, education extends the horizons, gives practical skills (competences), to free movement and adaptation, it should serve for participation and cooperation with others at all levels of human activities [17]. The process of shaping ecological awareness (ecological competences) is influenced by both its internal structure and external motivators in the form of educational activities. Gliński in the structure of ecological awareness indicates the following levels: intuitive conviction, intuitive conviction relating to consciousness of the danger and emotional level. The ecological consciousness structure referred to above indicates that everyone (as a first level) has some inherent conviction that the environment remains an important determinant of quality of life, and that, in the process of education and socialization, it also recognizes deeper relationships between human activity and the environment (level 2). There is a deeper understanding of the mechanisms (level 3) responsible for, inter alia, for environmental pollution [18]. Education for the CE requires interdisciplinary teaching, not just the transfer of theoretical knowledge, but, above all, development of attitudes. A closed-loop economy requires a greater level of environmental awareness, such as: the use of everyday electrical appliances (energy saving), prudent shopping (counterfeiting the waste of food products), reuse of 
spent goods (upcycling and raw material savings), collective transport (lower emissions), waste segregation and rational water management. While education for sustainable development affects the broadly understood activities already described above, education for the CE determines daily human activity in a narrow sphere, allowing it to make environmental daily choices at local level, to lead a sustainable way of life. On the one hand, it allows for further integral development of man, on the other, it prevents ecological imbalance, stimulates ecological action which is fundamental for the slogan think globally - act locally. The education of the circular economy plays a key role in this process, which empowers the person to become competent (ecologically), enabling him to develop without disturbing the ecological balance in a sustainable and responsible manner [21]. It can be stated that without education (building higher level of ecological awareness), it would not be possible to have a closed-loop economy. This ecologically conscious man is capable of daily actions resulting not only from orders and prohibitions, but from a broad understanding of himself and the environment in which he lives.

\section{CONCLUSIONS}

Man is a dynamic being. His calling is integral development which is achieved by means of various fields of progress (civilization, social, cultural, personal). Pursuit of this development allows the human person to retain his identity; Man fulfills himself as a rational and free being [1]. On the other hand, however, the human race has become so powerful that it has led to ecosystem imbalances and threatened its existence [19]. The path of rebuilding human solidarity with nature and at the same time further developing it, shall be seen in the sustainable development, which aims to improve the quality of life and the prosperity of both present and future generations. This can be achieved through the creation of societies that are resource efficient and exploit the potential of ecological and social innovation by ensuring prosperity and the environment protection. Environmental responsibility should encourage different behaviors that have a direct and significant impact on the environment protection. Pope Francis in the encyclical Laudato si' says to "avoid the use of plastics and paper, reduce water consumption, segregate waste" [20, p. 211].

Education empowers a person who is educated to implement the rules and principles of the circular economy, and allows for further sustainable development with respect for the environment. Education for the CE is an important element of education for sustainable development and complements it as an important tool for achieving this sustainable development. The importance of education for sustainable development is emphasized in all important international documents as a prerequisite for the implementation of sustainable development. The modern man should see, be able to identify and solve problems, make a correct and constructive decision, and this higher cognitive ability is a challenge to modern education [22].

Building ecological awareness, which involves shaping environmental attitudes and behaviors, should be a contemporary priority for education for a closed-loop economy. Ecological competences appear to be necessary for modern man, no matter what he does every day. Undoubtedly these are the core competences of the $21^{\text {st }}$ century man. Their lack may be the cause of self-destruction of the human race, which cannot be prevented by use of knowledge and competences from other areas of science and activity.

\section{REFERENCES}

[1] Wyrostkiewicz M. Human Ecology. Person and its environment from a moral-theological perspective. KUL, Lublin, 2007. (in Polish) 
[2] Kluczkowski A. Innovative ecological energy. Ed. 2. Center for Knowledge, Innovation and Development, Lublin, 2017. (in Polish)

[3] Sander J. Sustainable development as a chance for humanity. Cardinal Stefan Wyszynski University, Warsaw, 2008. (in Polish)

[4] Grodkiewicz P. Towards the economy by a closed circuit. Logistyka Odzysku, 1 (14) (2015), 14-17. (in Polish)

[5] Wyrostkiewicz M. Ecological dimensions of institutional education. Scientific Bulletin of Chetm, 7 (2) (2017), 83-92. (in Polish)

[6] Daly H. E. Sustainable development - definitions, principles, policies. In: Keiner M. The Future of Sustainability, 39-53. Springer, Dordrecht, 2006.

[7] Skowroński A. Sustainable development the perspective of further civilization progress. Problemy ekorozwoju, 1 (2) (2006), 47-57. (in Polish)

[8] General Assembly. Our Common Future: The World Commission on Environment and Development. Oxford University Press, Oxford, 1987.

[9] Morżoł I. UNESCO and sustainable development. Available at: http://www.unesco.pl. //www.unesco.pl/edukacja/dekada-edukacji-nt-zrownowazonego-rozwoju/unesco-a-zrownowazonyrozwoj. (in Polish)

[10] The Law on Environmental Protection of 27 April 2001. Official Journal of Laws, 50 (627) (2001).

[11] United Nations Conference on Environment and Development, Rio de Janeiro Declaration on Environment and Development. Available at: http://old.ko.poznan.pl/pub/ftp/Edukacja_zrownowazon ego_rozwoju/DEKLARACJA_Z_RIO_1992.pdf.(in Polish)

[12] United Nations Economic Commission for Europe. Education Strategy for Sustainable Development. In: Ministrestwo Środowiska. Available at: https://www.mos.gov.pl/g2/big/2009_04/4f3f267429420f4dfcb3 2b98f1ac8605.pdf. (in Polish)

[13] Borys T. Decade of education for sustainable development - Polish challenges. Problemy ekorozwoju Problems of sustainable development, 5 (1) (2010), 59-70. (in Polish)

[14] Gocko J. Economic dimension of the ecological issue. In: J. Nagórny, J. Gocko (Eds.) Ecology. The moral message of the Church. KUL, Lublin, 2002. (in Polish)

[15] Famuła-Jurczak A., Mazur P. (Towards) Educational to (not) known the future. In: The Russian world in the space-time context, 502-510. Publishing house of Altai State Technical University, Barnaul, 2015. (in Polish)

[16] Education. In: Encyklopedia PWN. Available at: https://encyklopedia.pwn.pl/haslo/edukacja; 3896542.html. (in Polish)

[17] Mazur P. Education in a spiral uncertain future. Horyzonty Wychowania, 9 (18) (2010), 105-113. (in Polish)

[18] Gliński P. Ecological awareness of Polish society - current research results. Kultura $i$ społeczeństwo, 3 (1988), 182-196. (in Polish)

[19] Bołoz W. Church and ecology. In defense of man and the natural environment. Homo Dei, Kraków, 2010. (in Polish)

[20] Francis. Encyclica letter Laudato si'. Libreria editrice Vaticana, Cittá dell Vaticano, 2015.

[21] Budnyk O. Ethnoeconomic competence of students. Publishing House "Plai" of IT Center of Vasyl Stefanyk Precarpathian National University, Kyiv-Ivano-Frankivsk, 2008. (in Ukrainian)

[22] Kandzia J. Formation of teaching and education in the process of mathematical education using multimedia techniques. Impuls, Kraków, 2011. (in Polish)

Address: Andrzej Kluczkowski, Michał Wyrostkiewicz, The John Paul II Catholic University of Lublin, 14, Aleje Racławickie, Lublin, 20-950, Poland.

E-mail: andrzejkluczkowski@gmail.com, m.wyrostkiewicz@gmail.com.

Received: 22.11.2017; revised: 12.03.2018. 
Клучковскі Анджей, Виросткєвіч Міхель. Циклічна економіка як важливий предмет екологічної освіти в епоху попиту на енергію. Журнал Прикарпатського університету імені Василя Стефаника, 5 (1) (2018), 88-94.

У статті обгрунтовано, що розвиток цивілізації призвів до створення багатьох об'єктів у житті та бізнесі сучасних людей, але також вніс істотні зміни, новий порядок, який з часом суперечить природнім процесам життедіяльності. Можливість узгодити екологічні, економічні та соціальні причини, на думку авторів, має бути знайдена в ідеї сталого розвитку. Передумовою для досягнення сталого розвитку слугує освіта, яка є одним із основних прав июдини та забезпечує цілісний іiі розвиток. Мета дослідження полягала у визначенні значення освіти у виникненні та реалізації ідеї кругової економіки. Як виявилося, дослідження засвідчили, що сталий розвиток значною мірою залежить від впровадження кругової економіки, в якій освіта є фундаментальним та необхідним інструментом.

Ключові слова: екологія, сталий розвиток, освіта, циклічна (кругова) економіка, екологічні компетенції. 